\title{
Meat Chemical Composition and Content of Macrominerals in Common Carp (Cyprinus Carpio L.) and Rainbow Trout (Oncorhynchus Mykiss W.), Cultivated in Different Production Systems
}

\author{
Stefka Stoyanova \\ Bulgaria, Stara Zagora 6000, Trakia University, Faculty of Agriculture, Department of Biology and Aquaculture
}

\begin{abstract}
The aim of the present study was to determine the chemical composition and content of macrominerals Ca, K, P, Na and Mg in the meat of common carp (Cyprinus carpio L.) and rainbow trout (Oncorhynchus mykiss W.) farmed in different production systems. The content of macrominerals was measured by atomic absorption spectrophotometry (AAS) in the Agricultural Research Laboratory of the Agricultural Faculty at the Trakia University. The differences in farming technologies did not affect the chemical composition of common carp muscles. In rainbow trout there were statistically significant differences in the chemical composition in relation to production systems. The chemical composition of rainbow trout meat differed in terms of crude protein and crude fat in both farming systems studied - in raceways and net cages. The protein content was significantly higher while crude fat content - considerably lower in the muscle of rainbow trouts grown in net cages. Carp muscle macrominerals in both cultivation techniques (in ponds and net cages) were arranged in the following order: $\mathrm{K}>\mathrm{P}>\mathrm{Ca}>\mathrm{Na}>\mathrm{Mg}$. In rainbow trouts cultivation in raceways, macrominerals were arranged in the following descending order $\mathrm{P}>\mathrm{K}>\mathrm{Na}>\mathrm{Mg}>\mathrm{Ca}$, while in the net cages: $\mathrm{K}>\mathrm{P}>\mathrm{Na}>\mathrm{Mg}>\mathrm{Ca}$.
\end{abstract}

Keywords: Cyprinus carpio, Oncorhynchus mykiss, mineral content, AAS, production systems

\section{Introduction}

The most cultivated fish species in Bulgaria are common carp (Cyprinus carpio L.) and rainbow trout (Oncorhynchus mykiss W.), the number of cultured channel catfish and sturgeons is also increasing. Carp is grown mainly in earth ponds and rainbow trout in raceways. During the last years, the number of farms in Bulgaria practicing cultivation of these species in net cages tended to increase The higher interest to carps and rainbow trouts is due to their rapid growth and the high nutritional value of the meat $[1,2,3,4,5]$. The high content of essential amino acids and protein in the meat [6] and the low fat content make it preferred for consumers. The biological value of fish meat protein is not different from that in the meat of other animals[7]. In the world, $15 \%$ of consumed animal protein originates from fish and fish products [8]. Daily protein needs of people can be satisfied with $400 \mathrm{~g}$ fish [7]. Fish muscles contain less connective tissue [9] compared to other farm animals (less collagen and insignificant amounts of elastin), therefore fish meat is quickly digested. The ash content of meat provides a measure of total mineral content in the tissues. Fish meat contains higher amounts of minerals, especially calcium, phosphorus, magnesium, potassium and significant amounts of vitamin D $[2,10]$. Studies of the minerals in living organisms are of biological importance, as many of them are involved in some metabolic processes and are essential to all living beings [11]. The muscles contain small amounts of these minerals, some of which are essential nutrients and components of many enzyme systems, contributing to the growth of the fish. The most important mineral elements are calcium, magnesium, potassium, phosphorus, iron and chlorine [12]. Their deficiency slows down blood clotting, causes a number of diseases, such as osteoporosis, anaemia, etc. $[11,13,14]$. The differences in the chemical composition of the fish body are caused by factors such as age, season of catching, ambient conditions, farming technology and nutrition [15]. Fish meat has high water (60 to 80\%) and low carbohydrate content under the form of glycogen [2]. Due to its high water content, this meat is more susceptible to spoilage compared to the meat of warm-blooded animals. The low fat content and the relatively low cholesterol content, as well as the significant content of minerals, vitamins and essential fatty acids make the fish one of the most valuable food products for humans $[16,17,18]$. The chemical composition of fish meat, apart from genetic factors, is also influenced by the quality of water, $\mathrm{pH}$, temperature and feed $[19,20,21,22,23]$. The chemical composition of meat depends on the climate in the region of the farm and the season, although the main differences come from variations in the amount and quality of feed and activity of fish [24]. Cahu et al. [25]noted that the meat of fish from aquaculture had a higher fat content than the meat of fish from natural habitats. The fat content increased proportionally to the size and the feeding level of the fish $[26,27]$. Fish meat protein content is stable during the growth period [28], except for the case of deficient and unbalanced diet [29]. The protein content in fish meat varies from 12 to $24 \%$ or about $18 \%$ on average, which is similar to the protein content of mammalian meat [30].

The aim of the present study was to determine the chemical composition and content of macrominerals $\mathrm{Ca}, \mathrm{K}, \mathrm{P}, \mathrm{Na}$ and $\mathrm{Mg}$ in the meat of common carp (Cyprinus carpio L.) and rainbow trout (Oncorhynchus mykiss W.) farmed in different production systems. 


\section{International Journal of Science and Research (IJSR)}

ISSN (Online): 2319-7064

Index Copernicus Value (2016): 79.57 | Impact Factor (2015): 6.391

\section{Material and methods}

For performing the studies, 6 common carps (Cyprinus carpio L.) and 6 rainbow trouts (Oncorhynchus mykiss W.) were selected from each of the following farms:

- Tunja 73, Nikolaevo town - production system for carp species, grown in earthen ponds;

- Forest group, Jrebchevo Dam - net cage production system for common carp and rainbow trout farming;

- Reya Fish, Dospat Dam - net cage production system for rainbow trout farming;

- Bukovets - Tvarditsa, Tvarditsa town - production system for rainbow trout farming in raceways.

The fish were transported in a cooling bag with ice to the laboratory of the Biology and Aquaculture unit and separated according to the species. The total body length $(\mathrm{L}$, $\mathrm{cm})$ and live weight (Bw, g) were measured. Then the specimens were rinsed with deionized water, placed in polythene bags and stored at $-20{ }^{\circ} \mathrm{C}$ until performance of tests.

The macromineral analysis ( $\mathrm{Ca}, \mathrm{K}, \mathrm{P}, \mathrm{Na}$ and $\mathrm{Mg}$ in $\mathrm{mg} / \mathrm{kg}$ ) and proximate analysis (water, dry matter, protein, fat and ash contents in \%) were carried out in the Research Laboratory of the Agricultural Faculty at the Trakia University, Stara Zagora. Samples for assays were taken from the dorsal muscle of fish. Pretreatment of muscle samples of common carp (Cyprinus carpio L.) and rainbow trout (Oncorhynchus mykiss W.) was done by wet ashing in microwave oven (Perkin Elmer Miltiwave 3000).
Meat samples were prepared according to AOAC (2006; method 983.18) and the following parameters were determined:

- Dry matter (\%), according to BDS 11374-86;

- Moisture (\%), according to BDS 11374-86;

- Content of proteins (\%), according to BDS-ISO 5983;

- Content of lipids (\%), according to BDS-ISO 6492;

- Mineral content (\%), according to BDS11374-86.

Macrominerals were assayed by atomic absorption spectrophotometry (AOAC, 2007) on Perkin Elmer atomic absorption spectrophotometer (AAS). The concentrations were calculated with the help of standard curves. For each element, a standard set of solutions were prepared to determine the content of each mineral in tested muscle samples. The content of $\mathrm{Ca}, \mathrm{K}, \mathrm{P}, \mathrm{Na}$ and $\mathrm{Mg}$ were measured in $\mathrm{mg} / \mathrm{kg}$.

ANOVA was used for statistical analysis of data (MS Office 2010).

\section{Results and Discussion}

The live weight and body length of the studied species under the two production systems are given on Figure 1. Total body length (L) and body weight (BW) of common carp grown in earthen ponds and net cages and rainbow trout kept in raceways and cages were similar.

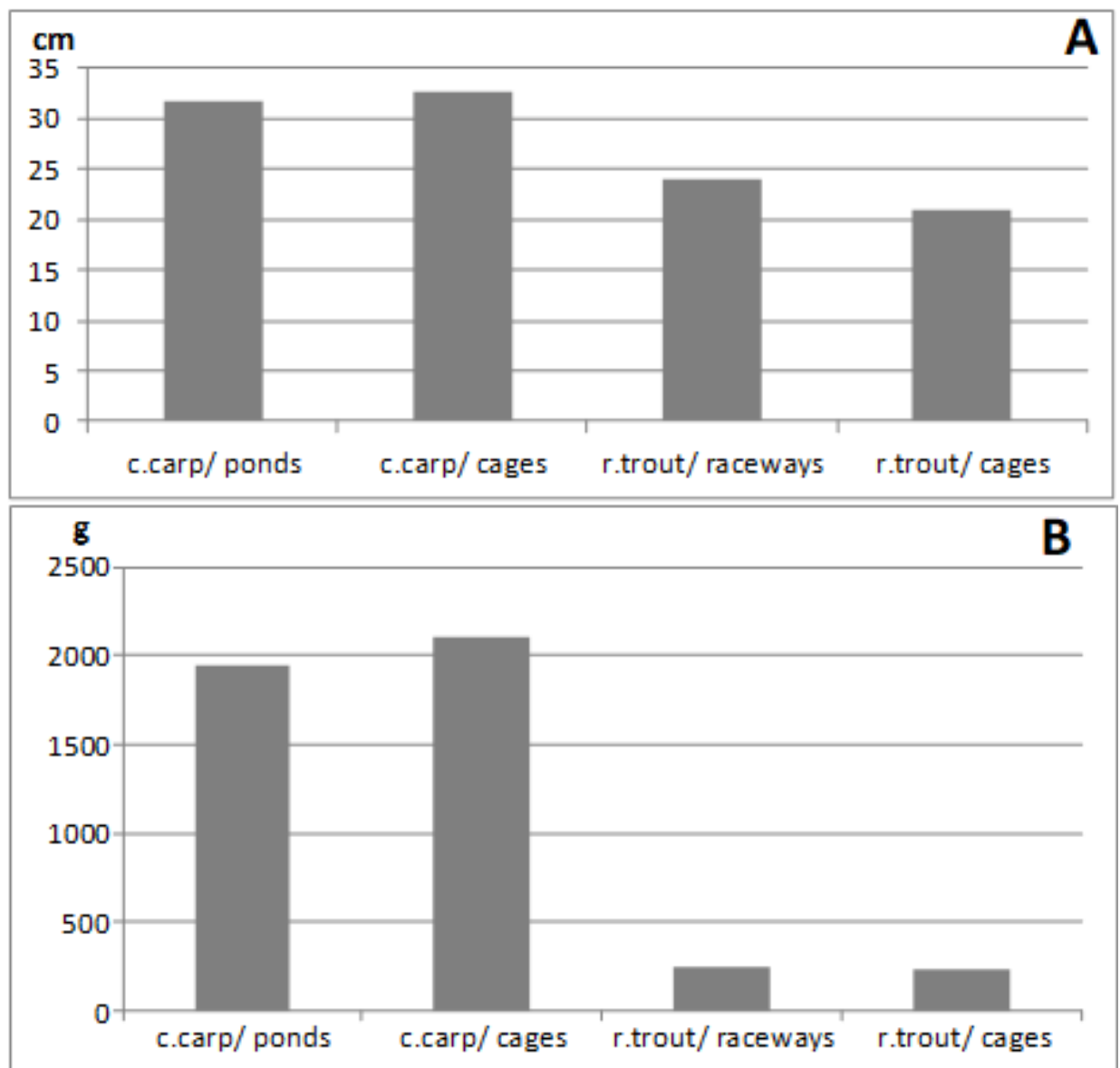

Figure 1: Measurements of the studied fish species: A) total body length (L) and B) body weight (BW)

Volume 6 Issue 12, December 2017 www.ijsr.net 


\section{International Journal of Science and Research (IJSR) \\ ISSN (Online): 2319-7064 \\ Index Copernicus Value (2016): 79.57 | Impact Factor (2015): 6.391}

The chemical composition of meat of studied fish species is presented in Table 1.

Table 1: Proximate analysis of fish muscle, (\%)

\begin{tabular}{|c|c|c|c|c|c|c|}
\hline Production systems & $\mathrm{n}$ & Moisture & Dry matter & Protein & Lipids & Ash \\
\cline { 2 - 7 } & $\overline{\mathrm{x} \pm \mathrm{SD}}$ & $\overline{\mathrm{x} \pm \mathrm{SD}}$ & $\overline{\mathrm{x}} \mathrm{SD}$ & $\overline{\mathrm{x} \pm \mathrm{SD}}$ & $\overline{\mathrm{x} \pm \mathrm{SD}}$ \\
\hline & \multicolumn{7}{|c|}{ Common carp } \\
\hline ponds & 6 & $76,16 \pm 0,267$ & $23,84 \pm 0,267$ & $17,66 \pm 0,440$ & $4,78 \pm 0,188$ & $1,39 \pm 0,014$ \\
\hline net cages & 6 & $76,11 \pm 0,089$ & $23,89 \pm 0,089$ & $17,15 \pm 0,133$ & $4,74 \pm 2,300$ & $1,11 \pm 0,082$ \\
\hline \multicolumn{7}{|c|}{ Rainbow trout } \\
\hline raceways & 6 & $76,69 \pm 0,160$ & $23,31 \pm 0,161$ & $16,98 \pm 0,049 \mathrm{a}$ & $4,71 \pm 0,038 \mathrm{~b}$ & $1,36 \pm 0,016 \mathrm{c}$ \\
\hline net cages & 6 & $77,14 \pm 0,622$ & $22,86 \pm 0,622$ & $17,05 \pm 0,029 \mathrm{a}$ & $3,94 \pm 0,094 \mathrm{~b}$ & $1,12 \pm 0,019 \mathrm{c}$ \\
\hline
\end{tabular}

The differences between the averages in a vertical row with the same letters are statistically significant: $a-a-p \leq 0.01 ; b-b$ , $\mathrm{c}-\mathrm{c}-\mathrm{p} \leq 0.001$.

There were no differences in the values of meat chemical indicators of carps grown in ponds and net cages. The data from carp meat proximate analysis showed that in both production technologies, the moisture, crude protein, crude fat and crude ash contents were similar. In rainbow trouts there were significant differences in meat crude protein, crude fat and crude ash contents of fish reared either in raceways or net cages. The obtained results are similar to those found of [7] for rainbow trout meat. Rainbow trout is considered a medium oily fish with a meat lipid content of 2 to 7\% [31]. Vranić et al.[7] found that the meat protein and mineral content was lower and the fat content was higher in cultivated rainbow trouts compared to Brown Trouts (Salmo trutta fario). Controlled conditions for fish farming imply the production of fish with the equal and constant meat chemical composition.

Meat macromineral content of the two studied fish species is presented in Table 2.

Table 2: Content of macroelements in the muscles of common carp (Cyprinus carpio) and rainbow trout(Oncorhynchus mykiss), $\mathrm{mg} / \mathrm{kg}$

\begin{tabular}{|c|c|c|c|c|c|c|}
\hline Production technologies & $\mathrm{n}$ & $\mathrm{Ca}$ & $\mathrm{K}$ & $\mathrm{P}$ & $\mathrm{Na}$ & $\mathrm{Mg}$ \\
\cline { 3 - 7 } & & $\overline{\mathrm{x}} \pm \mathrm{SD}$ & $\overline{\mathrm{x}} \pm \mathrm{SD}$ & $\overline{\mathrm{x}} \pm \mathrm{SD}$ & $\overline{\mathrm{x}} \pm \mathrm{SD}$ & $\overline{\mathrm{x}} \pm \mathrm{SD}$ \\
\hline \multicolumn{7}{|c|}{ Common carp } \\
\hline Ponds & 6 & $625,28 \pm 16,991$ & $3446,49 \pm 19,391$ & $2426,49 \pm 39,666$ & $583,72 \pm 6,640$ & $487,58 \pm 11,361$ \\
\hline net cages & 6 & $612,55 \pm 24,438$ & $3629,90 \pm 13,182$ & $2407,65 \pm 42,791$ & $525,74 \pm 8,229$ & $488,74 \pm 13,937$ \\
\hline \multicolumn{7}{|c|}{ Rainbow trout } \\
\hline Raceways & 6 & $140,51 \pm 0,187 \mathrm{c}$ & $2691,54 \pm 0,543 \mathrm{~b}$ & $2848,10 \pm 0,388 \mathrm{a}$ & $662,55 \pm 0,333 \mathrm{~d}$ & $307,15 \pm 0,042 \mathrm{e}$ \\
\hline net cages & 6 & $112,3 \pm 0,260 \mathrm{c}$ & $2610,01 \pm 0,021 \mathrm{~b}$ & $2311,38 \pm 0,0,231 \mathrm{a}$ & $671,07 \pm 0,027 \mathrm{~d}$ & $247,17 \pm 0,107 \mathrm{e}$ \\
\hline
\end{tabular}

The differences between the averages in a vertical row with the same letters are statistically significant: $a-a-p \leq 0.05 ; b-b-p$ $<0.01$; c-c, d-d, e-e $\mathrm{p} \leq 0.001$.

In carps reared in both production systems, the $\mathrm{K}$ content was the highest from all studied macrominerals and that of $\mathrm{Mg}$ - the lowest. Rainbow trout meat has the highest content of phosphorus $(2848,10 \pm 0,39 \mathrm{mg} / \mathrm{kg}$ ) in raceways, but highest content of $\mathrm{K}$ in net cages $(2610,01 \pm 0,02)$. In both technologies, calcium content in fish muscle was the lowest.

Authors having studied the mineral composition of fish muscle, also established various contents of mineral elements in different species of fish [12]. In our study, the content of the main elements in carp meat under both production technologies was in the following order: $\mathrm{K}>\mathrm{P}>$ $\mathrm{Ca}>\mathrm{Na}>\mathrm{Mg}$. In rainbow trouts there were differences in the content of mineral elements according to the technology of farming. In raceways, the macrominerals in descending order were $\mathrm{P}>\mathrm{K}>\mathrm{Na}>\mathrm{Mg}>\mathrm{Ca}$, while in the net cages: $\mathrm{K}>$ $\mathrm{P}>\mathrm{Na}>\mathrm{Mg}>\mathrm{Ca}$.

\section{Conclusions}

- The chemical composition of common carp meat (Cyprinus carpio L.) did not differ depending on the farming technology - in earthen ponds or net cages.

- The chemical composition of rainbow trout meat (Oncorhynchus mykiss W.) differed in terms of crude protein and crude fat in both farming systems studied - in raceways and net cages. The protein content was significantly higher while crude fat content - considerably lower in the muscle of rainbow trouts grown in net cages.

- In the meat of common carp cultivated in earthen ponds and in net cages, the highest content was that of potassium and the lowest - of magnesium.

- In the meat of rainbow trout in raceways, the highest content was that of phosphorus and in net cages: of potassium content. For both technologies, the lowest content in fish muscle was that of calcium.

\section{References}

[1] Tikeogly N. 2000. Ic Su Baliklari Yetistiriciligiri, Cukorova Universitesi $\mathrm{Su}$ Urunleri Fakultesi Ders Kitabi, 2, Adana, Turkey.

[2] Ćirković M., Jovanović B., Maletin S. 2002. Ribarstvo, biologija, tehnologija, ekologija, ekonomija. Novi Sad, 213.

[3] Gladyshev M.I., Sushchik N.N., Gubanenko G.A., Demirchieva S. M., Kalachova G.S., (2006). Effect of way of cooking on content of essential polyunsaturated fatty acids in muscle tissue of humpback salmon /Oncorhynchus gorbuscha/. Food Chemistry 96, 446451.

\section{Volume 6 Issue 12, December 2017}




\section{International Journal of Science and Research (IJSR) \\ ISSN (Online): 2319-7064 \\ Index Copernicus Value (2016): 79.57 | Impact Factor (2015): 6.391}

[4] Burger J. and Gochfeld M. 2009. Perceptions of the risks and benefits of fish consumption: Individual choices to reduce risk and increase health benefits. Environmental Research, 109, 343-349.

[5] Ljubojevic D., Trbovic D., Lujic J., Bjelic-Cabrilo O., Kostic D., Novakov N. and Cirkovic M. 2013. Fatty acid composition of fishes from inland waters. Bulgarian Journal of Agricultural Science, 19 (Supplement 1), 62-71.

[6] Michalczyk M and Surówka K. 2007. The effects of gravading process on the nutritive value of rainbow trout /Oncorhynchus mykiss/. Journal of Fisheries Sciences.com. 1,3, 130-138.

[7] Vranić D., Đinović-Stojanović J., Spirić A. 2011. Rainbow trout /Oncorhynchus mykiss/ from aquaculture - meat quality and importance in the diet.Tehnologija mesa,52,122-133.

[8] Anonymous 1999. Federal Agriculture Organization, www.fao.org

[9] Kałakowska A. and Kałakowski E. 2001. Fish nutritive value. Przemysł Spożywczy 55,6,10-13.

[10] Anonymous 2003. Nutritional aspects of fish, Bord Iascaigh Mhara/ Irish Sea Fischeries Board, Dun Laoghaire Co., Dublin.

[11] Shu'lman G.E.1974. Life cycle of fish: Physiology and Biochemistry, Halsted Press, a division of John Wiley and Son Inc. N Y (1st Ed), 101-104.

[12] Abdul H. and Sarojnalini C. 2012. Proximate Composition, Macro and Micro Mineral Elements of Some Smoke-dried Hill Stream Fishes from Manipur, India. 2010. Nature and Science, 10 (1).

[13] Mills C.F.1981. The mineral composition of livestock (Underwood EJ, Ed.) Common Wealth Agricultural Bureaux, 9.

[14] Valkova E., Atanasov V., Bivolarski B, Bozakova N, Valkova P. 2013. Study on levels of $\mathrm{Cu}$ in liver, ovaries, testes and musculature of hydrobionts from waterbodies in Stara Zagora region, Bulgaria. Journal of Animal Science,50, 1, 53-61.

[15] Hadzhinikolova L. and Atanasova R. 2007. Seasonal and age related dynamics of chemical composition of carp meat reared in ponds. Journal of Animal Science, $54,60-64$.

[16] Conor W.E. 2000. Importance of n23 fatty acids in health and disease. American Journal of Clinical Nutrition, 171-175.

[17] Abdullahi S.A., Abolude D.S. and Ega R.A., 2001. Nutrient quality of four oven dried freshwater catfish species in Northern Nigeria. Journal of Tropical Biosciences, 1(1),70-76.

[18] Sidhu K.S. 2003. Health benefits and potential risks related to consumption of fish or fish oil. Regulatory Toxycology and Pharmacology, 38, 3, 336-344.

[19] Reinitz J.1983. Variation of body composition and growth among strains of rainbow trout. Transactions of the American Fisheries Society.108,204-207.

[20] Fauconneau B., Alami-Durante H., Laroche M., Marcel J., Vallot D. 1995. Growth and meat quality relations in carp. Aquaculture, 129, 265-297.

[21]Buchtova H., Svobodova Z., Križek M., Vacha F., Kocour M., Velišek J. 2007. Fatty acid composition in intramuscular lipids of experimental scaly crossbreds in 3-year-old common carp /Cyprinus carpio L./. Acta Veterinaria Brno, 76, 73-81.

[22] Menoyo D., Lopez-Bote C. J., Diaz A., Obach A., Bautista J. M. 2007. Impact of n-3 fatty acid chain lenght and n-3/ n-6 in Atlantic salmon /Salmo salar/ diets. Aquaculture, 276, 248-259.

[23] Valkova, E., V. Atanasov, K. Velichkova, G. Kostadinova, M. Tzanova, 2015. Chromium level in water, sediment, aquatic plants and meat of common carp /Cyprinus carpio L./ from different water bodies in Bulgaria, Agriculture Science and Technology, 7,3, 334338.

[24] Murray J., Burt JR.2009. The composition of fish, Torry Advisory Note No.3 www.fao.org/wairdocs/tan/x5916e/x5916e00.htm, 27-2.

[25] Cahu C., Salen P., de Lorgeril M. 2004. Farmed and wild fish in the prevention of cardiovasular diseases: Assessing possible differences in lipid nutritional values. Nutrition Metabolism and Cardiovascular Diseases, 14, 34-41.

[26] Kaushik S. J. 1995. Nutrient requirements, supply and utilization in the contest of carp culture. Aquaculture, 129, 225-241.

[27] Danijela V, Milan BŽ, Dejana T, Jasna ĐS, Radmila M, Radivoj P, Aurelija S.2012. Mlađ i konzumna kalifornijska pastrmka /Oncorhynchus mykiss/: hemijski sastav, sadržaj holesterola i masnokiselinski sastav fi leta.Tehnologija mesa 53, 1, 26-35.

[28] Shimeno S., Kheyvyali D., Takeda M. 1990. Metabolic adaptation to prolonged starvation in carp. Nippon Svisan Gakkaishi, 56, 35-41.

[29]Zeitler M. H., Kirchgessner M., Schwarz F. J. 1984 Effects of different protein and energy supply on carcass composition of carp /Cyprinus carpio L./. Aquaculture, 36, 37-48.

[30] Cvrtila Ž. I. and Kozačinski L. 2006. Kemijski sastav mesa riba. Meso, 7, 6, 365-370.

[31] Jobling, M.2001. Nutrient partitioning and the influence of feed composition on body composition. In: Houlihan D., Boujard T., Jobling M. (eds.): Food Intake in Fish. Blackwell Science Ltd, Oxford, 414. 